\title{
5. és 6. évfolyamos tanulók nemzeti szimbólumokkal kapcsolatos ismereteinek jellemzői - egy technológia alapú mérés tanulságai
}

\author{
Dancs Katinka*
}

A tantervi dokumentumokban célként jelenik meg a nemzeti identitás fejlesztése, azonban arra vonatkozóan nem rendelkezünk információkkal, hogy milyen jellemzői vannak a tanulók nemzeti identitásának. Kutatásunkban azt a célt túztük ki, hogy mérjük a tanulók teljesítményét a nemzeti identitással összefüggő ismeretelemekkel, a nemzeti szimbólumokkal kapcsolatban. A nemzeti szimbólumok a nemzeti kultúra elemei, a történeti narratívákban helyet kapó személyek, események, helyszínek vagy tárgyi alkotások. Több lépésben meghatároztuk a tantervekben szereplő nemzeti szimbólumokat, majd ezek felhasználásával tesztet készítettünk. Eredményeink szerint tesztünk segítségével jellemezni tudjuk a tanulók tudását, átlagosan 64,78\%-os teljesítményt értek el. Az idősebb tanulók jobban teljesítettek, míg a nemek között nem találtunk különbséget. A nemzeti identitás elemei közül vizsgáltuk a tanulók azono sulásának erősségét is. A 6. évfolyamosok gyengébb azonosulást tanúsítottak, nemi különbséget ebben az esetben sem találtunk. Megvizsgáltuk a teszteredmények és az azonosulás erőssége közötti kapcsolatot is. Mindkét évfolya mon kapcsolat mutatható ki a változók között, azonban az együttjárás mértéke alacsony. A tanulók teljesítménye ugyanakkor korrelál az iskolai teljesítményükkel való elégedettségükkel, ami megerősíti, hogy a tananyagban helyet kapó ismereteket mérte tesztünk. Számítógép-alapú mérésünk lehetővé tette, hogy a tesztkitöltés körülményeiről is adatokat gyújtsünk. Nem találtunk összefüggést a tanulók teljesitménye és tesztre fordított ideje között, azonban az idő és az iskolába járás iránti pozitiv attitüd között igen. Ez az eredmény azt erősíti meg, hogy nem a tanulók tudás szintje befolyásolja a kitöltésre fordított időt, hanem inkább attitűdjeik befolyásolják azt. Kutatásunk az első lépés volt annak érdekében, hogy megismerjük az iskola identitáskonstrukcióban betöltött szerepét.

Kulcsszavak: általános iskola, tudásszintmérés, állampolgári kompetencia, nemzeti identitás, számítógép-alapú mérés

\section{Bevezetés}

A nemzetközi szakirodalom nemzeti enkulturációnak (Barrett, 2007) nevezi a nemzeti kultúra közvetítésének folyamatát, ezzel utalva arra, hogy egy egész életen át tartó folyamatról van szó, amelyben formális és informális közvetítők egyaránt fontos szerepet töltenek be. Az iskola a központilag meghatározott tananyagon keresztül szabályozza az elsajátítandó kulturális tartalmakat, míg a család, a kortársak és a média kultúraközvetítése az informális tanulás lehetőségeit teremtik meg. A kultúraközvetítés többszörös funkciót lát el. Egyrészt a társadalmivá válást, a felnőtt létre való felkészülést szolgálja, ugyanakkor megteremti az összetartozás érzését, a közös identitástudatot. A nemzeti közösség történelmi, szellemi és technikai teljesítményének, viselkedési normáinak, értékeinek, szokásainak és hagyományainak átadása így válik a nemzeti azonosságtudat megalapo zásának és fejlesztésének eszközévé.

Napjainkban az iskolával szemben támasztott fő elvárás, hogy felkészítse a tanulókat az információs társadalom kihívásaira, előmozdítsa az élethosszig tartó tanuláshoz szükséges képességek és viszonyulások kialakulását (Csapó, 2003). A modern kihívások nem szorították háttérbe a hagyományos tananyagot, az továbbra is

A Szegedi Tudományegyetem Neveléstudományi Doktori Iskolájának doktorjelöltje, a Szegedi Tudományegyetem Neveléstudományi Intézetének tanársegéde. dancs@edpsy.u-szeged.hu 
főként a nemzeti kultúra elemeiből építkezik, feltételezhetjük, hogy e tananyag közvetítésén keresztül az iskola szerepet játszik a nemzeti identitás konstrukciójában. Az iskola kezdő szakaszában a tanulók az írás és olvasás elsajátításakor, vagy később, az irodalomtanítás alkalmával olyan szövegekkel találkoznak, amelyek a nemzeti történelmi eseményeiről, Magyarország látnivalóiról vagy neves személyiségeiről szólnak. Ugyanígy a természetismeret, a történelem, a földrajz, a rajz és az ének-zene tantárgyak is közrejátszanak a nemzeti kultúra elemeinek, narratíváinak közvetítésében.

A Nemzeti alaptanterv (NAT, 2012) az iskolai nevelés direkt céljai között említi a nemzeti azonosságtudat fejlődésének segítését. Kevés információnk van azonban arra vonatkozóan, hogy egyáltalán milyen jellemzői vannak az általános iskolás tanulók nemzeti identitásának, milyen irányú fejlődés jellemzi, illetve az iskola mi Iyen hatást gyakorol a fejlődésére. Ezeknek a kérdéseknek a tisztázása komplex kutatásokat igényel. Tanulmányukban egy olyan technológiaalapú mérés eredményeit mutatjuk be, amelyben a tanulók nemzeti szimbólu mokkal kapcsolatos tudásszintjének mérését tǔztük ki célul. A nemzeti szimbólumok olyan személyek, események, területek vagy éppen alkotások, amelyeknek a nemzet tagjai szimbolikus jelentést tulajdonítanak, nemzeti identitásuk kifejezőeszközeinek tekintenek. Kutatásunk részeként olyan online teszteket dolgoztuk ki, amelyek segítségével arra keressük a választ, hogy az iskolai tananyagban megjelenő nemzeti szimbólumokat milyen szinten sajátították el a tanulók. Emellett vizsgáltuk azt is, hogy az iskolában elsajátított ismeretek és a tanulók nemzeti azonosulásának erőssége összefügg-e egymással. A jelenségek közötti kapcsolat vizsgálatával az volt a célunk, hogy bizonyítékot találjuk arra, hogy a nemzeti szimbólumok elsajátítása lehet-e a nemzeti identitás fejlesztésének egyik eszköze. Végül a számítógép-alapú mérés lehetőségeit kihasználva, a tanulók tesztviselkedésének jellemzésére is vállalkozunk.

\section{A nemzeti identitás jellemzői}

Az identitás a társadalomtudományok központi fogalma, amellyel a történettudomány, a szociológia és a pszichológia is élénken foglalkozik. A történettudományi kutatások abban segíthetnek, hogy meghatározzuk a nemzet fogalmát, valamint a nemzeti identitás kialakulásában szerepet játszó folyamatokat, tényezőket.

A nemzet elképzelt emberi közösség, abban az értelemben, hogy mérete miatt lehetetlen az összes tag közötti közvetlen személyes kapcsolat és interakció. Ennek ellenére a tagok felismerik összetartozásukat, és egy közösség tagjaként definiálják önmagukat (Anderson, 1983/2006). Összetartozásuk észlelésének és megélésének alapja a közösnek tekintett múlt, melyben a nemzet tagjait érintő események, valamint a múltban gyökerező hagyományok és szokások kapnak helyet (Cohen, 1985/2001; Renan, 1995). A közös múlt mellett számos olyan tényezőt észlelnek közvetlenül a nemzet tagjai a jelenben is, melyek erősítik az összetartozás érzését. Ilyen tényezőnek számít a nyelv, a közös kultúra, valamint a nemzet megkülönböztetéséhez és behatárolásához használt szimbólumok (Smith, 2009).

Az egyén a szocializációs folyamatok során megismeri, elsajátítja a kollektív emlékezet elemeit (Assmann, 1999). A közösség emlékezetében helyet kapó narratívák kiemelt szerepet játszanak az összetartozás érzésének megteremtésében, hozzájárulnak a nemzeti identitás konstrukciójához (László, 2012). A narratívákban megjelennek különböző ismeretelemek is, melyeket a szakirodalom többféleképpen is nevez. A történettudományi kutatásokban nemzeti szimbólum kifejezéssel jelölik azokat a tudáselemeket, melyeket a nemzeti kultú ra fontos részének tartanak (Smith, 1991). A szimbólumok a nemzet elképzelt közösségének (Anderson, 1983/2006) útjelzőiként funkcionálnak, erős érzelmi töltettel rendelkeznek. További fontos jellemzőjük, hogy egy esemény, terület vagy személy akkor kezelhető szimbólumként, ha egy közösség azt annak tekinti (Cohen, 
1985/2001). A történettudományi kutatásokban, a kollektív emlékezetben helyet kapó események, helyszínek, személyek összegzőjeként megjelenik az emlékezethely fogalma is (Nora, 2009), amely a nemzeti szimbólu mokhoz hasonló tulajdonsággal rendelkezik. Mindkettőről elmondható, hogy a nemzeti csoport számára fontos események, személyek, területek, tárgyak vagy éppen múvészeti alkotások sorolhatók ide, melyeknek szimbo likus jelentést tulajdonítanak a nemzet tagjai. Jelentésük részben kanonikus, a közösség által elfogadott jelen tésen alapul, ugyanakkor nyitott az egyéni értelmezésekre is; végezetül mindkettőhöz érzelmek kapcsolódnak. Mivel a szimbólum kifejezés ismertebb, valamint utal arra, hogy a jelzett dolgok önmagukon túli jelentéssel is bírnak, ezért a továbbiakban ezt a kifejezést használjuk.

A nemzeti identitással foglalkozó hazai szociológiai kutatások a társas identitás elméletéből (Tajfel \& Turner, 1979) kiindulva az egyén csoporttagságát, a számára fontos közösségekkel való azonosulását tekintik a nemzeti identitás alapjának. A kutatások azt vizsgálják, hogy milyen tényezők vesznek részt a nemzeti identitás konstrukciójában, a társadalomban milyen identitásmintázatok tárhatók fel, valamint az azonosságtudat milyen más társadalmi jelenségekkel (például előítélet, szociokulturális közeg) függ össze.

A hazai kutatások az állampolgári szocializáció szerepét emelik ki a nemzeti identitás konstrukciójában, ugyanakkor felhívják a figyelmet a politikai szocializáció identitásformáló erejére is (Szabó, 2004, 2010). A tanulókkal foglalkozó kutatások elsősorban a serdülőket vizsgálják, és arra keresik a választ, hogy milyen kritériumok alapján határozzák meg a diákok a magyarságot, valamint milyen vélekedések kapcsolódnak a saját nem zethez és más nemzetekhez (Dancs, 2016). A felnőttekkel foglalkozó kutatások ezek mellett arra keresik a választ, hogy milyen mintázatok figyelhetők meg, azaz a nemzeti identitáshoz kapcsolódóan milyen attitúdök, vélekedések vannak jelen a társadalomban (Csepeli, 2002; Csepeli, Örkény, Székely, \& Poór, 2004).

A pszichológiai kutatások segítenek a nemzeti identitás pszichikus rendszerben betöltött szerepének tisztázásában, jellemzőinek meghatározásában. Az identitás értelmezésekor Pataki (2008, 2011) én-meghatározásából indulunk ki, miszerint az én a személy önmagáról való tudását tömöríti; olyan összetett rendszer, amelyet multifunkcionalitás jellemez. Tudáselemei mentális, érzelmi és viselkedésekhez kötődő reprezentációk, melyek a pszichikus rendszerben képződnek le. Komplexitását a tudásrendszerben mutatkozó egyéni különbségek és az egyes tudáselemek helyzeti aktiválódása adja, hagyományosan kétféle forrását, és ezzel együtt kétféle al rendszerét szokás megkülönböztetni. Egyrészt beszélhetünk az önreflektív gondolkodás eredményeként nyert éntudásról, mely a személyes énben képeződik le, másrészt a személy közösségeknek is tagja, a csoporttagságot belsővé teszi, beépíti énképébe, ezzel párhuzamosan a csoportok jellemzőit az egyén bizonyos mértékig önmagára is vonatkoztatja, így létrehozva társas énjét (Oyserman, Elmore, \& Smith, 2012). Végezetül meg kell említeni, hogy újabban a szakirodalom megkülönbözteti az interperszonális helyzetekből önmagunkra vonatkoztatott éntudást is, ami a relációs énben képeződik le (Brewer \& Gardner, 1996; Swann Jr \& Bosson, 2011; Sedikides, Gaertner, \& O'Mara, 2011).

A nemzeti identitás a többi identitáskategóriához hasonlóan az énrendszer társas eredetú alrendszeréhez tartozik, de ez nem jelenti azt, hogy az önreflexiónak vagy a társas kapcsolatokból származó tapasztalatoknak nincs szerepe elemeinek gyarapodásában. Ha szerkezeti szempontból közelítjük meg az énrendszert, akkor azt mondhatjuk, hogy az identitás az énkép része (Bennett \& Sani, 2004; Oyserman, Elmore, \& Smith, 2012), an nak különálló eleme, amely a csoporttagságból fakadó reprezentációk összessége, a társas én eleme (Stryker \& Burke, 2000). A gyermekek kognitív és szociális fejlődésével párhuzamosan fejlődik az énrendszer. A fejlődésben kezdetben az önészlelés játszik szerepet, majd az óvodáskor, de még inkább az iskoláskor idején a gyerekek egyre fogékonyabbá válnak a környezetükből érkező visszajelzésekre. A külső forrásokból származó vissza- 
jelzések énrendszerbe való beépülésével párhuzamosan enyhül a tanulók egocentrizmusa, gyarapodik a társas és a relációs én, kialakulnak az identitáskategóriák (Rosen \& Patterson, 2011; Harter, 2012).

Az eddigiek alapján a következő megállapításokat tehetjük a nemzeti identitással kapcsolatban: A nemzeti identitás egyike az egyén énrendszerében helyet kapó identitáskategóriáknak, kifejezi, hogy a személy a nemzet elképzelt közösségének tagjaként tekint önmagára, a szocializációs folyamatok eredményeként alakul ki, a közös kultúrának és a kollektív emlékezetnek fontos szerepe van abban, hogy megteremti azt az értelmezési keretet, amelyben az egyén elhelyezi önmagát. Végezetül megállapíthatjuk azt is, hogy a nemzeti identitás az énkép részét képezi, valamint sokféle reprezentáció (például attitúdök és vélekedések) vizsgálatára nyílik lehetőség a nemzeti identitással összefüggésben. A következőkben áttekintjük ezeket a reprezentációkat.

\section{A nemzeti identitás tudáskészletének elemei általános iskolás korban}

Általános iskolások esetében a nemzeti identitással összefüggésben sokféle reprezentáció vizsgálatára nyílik lehetőség: beszélhetünk kognitív, affektív és viselkedéses elemeket érintő reprezentációkról. A kognitív elemek közé tartozik a nemzeti csoport létének ismerete, az önkategorizáció, azaz hogy az egyén önmagát az adott csoport tagjának tekinti, a nemzettel összefüggésbe hozható földrajzi ismeretek, képzetek, a nemzeti kultúra szimbolikus elemeinek ismerete, valamint vélekedések, mint például sztereotípiák vagy tévképzetek a nemzeti történelemmel kapcsolatban. Az affektív elemek közé tartozik, az adott identitáskategória erősségének mértéke, a nemzethez, valamint annak földrajzi területéhez való kötődés és a nemzettel kapcsolatos egyéb attitúdök (például attitúdök a magyar nyelvvel, zászlóval kapcsolatban stb.). Végezetül a viselkedéses elemek közé tartoznak szokások és rutinok, amelyek a nemzeti identitás kifejezésével, ahhoz kötődő tevékenységek végzésével kapcsolatosak (például részvétel megemlékezéseken) (Barrett, 2007).

Az identitáskategóriával összefüggésben vizsgálható reprezentációk köre széles, éppen ezért felvetődik az a kérdés, hogy melyek pontosan azok az elemek, amelyek az identitás magját adják, azaz ténylegesen az énkép részét képezik, és melyek azok, amelyek nem az énkép elemei, viszont ettől függetlenül a nemzeti identitás tudáskészletének elemei. Ennek megállapításához azt a kérdést kell megválaszolnunk, hogy melyek azok a reprezentációk, amelyek hozzájárulnak az egyén éntudásához.

A viselkedéses elemek vizsgálata a legkevésbé elterjedt a kutatásokban, ami miatt kevés információ áll rendelkezésünkre ezek jellemzőiről, működéséről. További kutatások szükségesek ezek tisztázásához, ezért munkánk tovább részében a nemzeti identitás kognitív és affektív elemeire fókuszálunk. Ezek esetében az önkategorizáció, a vélekedéseken belül a sztereotípiák, valamint az identitás fontossága tekinthetők olyan reprezentációknak, amelyek az énkép részét képezik. Az önkategorizáció annak a mentális leképeződése, hogy a személy az adott csoport tagjaként tekint önmagára. Ez a tudás egyértelmúen az énkép részét képezi, tudósít arról, hogy mely csoportokban rendelkezik az egyén tagsággal, mely csoporttagságok épültek be az énrendszerbe. Ehhez kapcsolódik az identitás fontossága, ami arról nyújt információt, hogy a személy énjében milyen súllyal jelenik meg ez az identitáskategória, mennyire fontos számára az adott csoport. A gyerekek nemzeti identitásával foglalkozó kutatások ennek megfelelően vizsgálják, hogy a gyermekek a nemzeti közösség tagjaként tekintenek-e önmagukra, illetve a számukra releváns identitáskategóriák sorba rendezésével vizsgálják, hogy más identitáskategóriához viszonyítva mennyire fontos számukra az adott kategória (Barrett, Wilson, \& Lyons, 2003, Reizábal, Valencia, \& Barrett, 2004).

A sztereotípiák esetében, habár csoportjellemzőkről van szó, az egyén önmagára is vonatkoztat ebből információkat, például azt, hogy mennyire felel meg a sztereotípiában helyet kapó tulajdonságoknak. Davis (2007) 
kutatásában bizonyítékot talált arra, hogy a magasabb önértékeléssel rendelkező tanulók pozitívabban értékelték csoportjukat, mint másokat. Ez az eredmény arra utal, hogy a csoportértékelés és az önértékelés bizonyos esetekben összefügg, azonban a kapcsolat irányát nem ismerjük, így nem tudhatjuk, hogy a magasabb önértékelés vezet a csoportok pozitívabb értékeléséhez vagy fordítva. Ez az eredmény azonban rámutat arra, hogy az identitáskategóriák elemei kapcsolatba hozhatók az énrendszer más elemeivel is.

A további elemekről azt mondhatjuk, hogy nem képezik az énkép részét, viszont az identitáskategóriával összefüggő reprezentációkról van szó, amelyeket gyakran vizsgálnak a kutatások (Dancs, 2016). Kapcsolatuk sokféle lehet a nemzeti identitás magját képező elemekkel. Feltételezhetjük, hogy az énkép elemeként funkcionáló reprezentációk előhívása aktiválja ezen elemeket, ugyanakkor a kapcsolat fordított irányú is lehet, azaz a pszichikus struktúrában tárolt reprezentációk múködésbe lépése aktiválja az énképben helyet kapó elemeket (l. 1. ábra). Végezetül, ha nem is mutatható ki minden esetben a kapcsolat a változók két csoportja között, a pszichikus rendszerben helyet kapó elemek vizsgálata segíthet annak megértésében, hogy milyen tudáselemekkel rendelkezik a személy az identitáskategóriához tartozó csoportról, esetünkben a nemzetről.

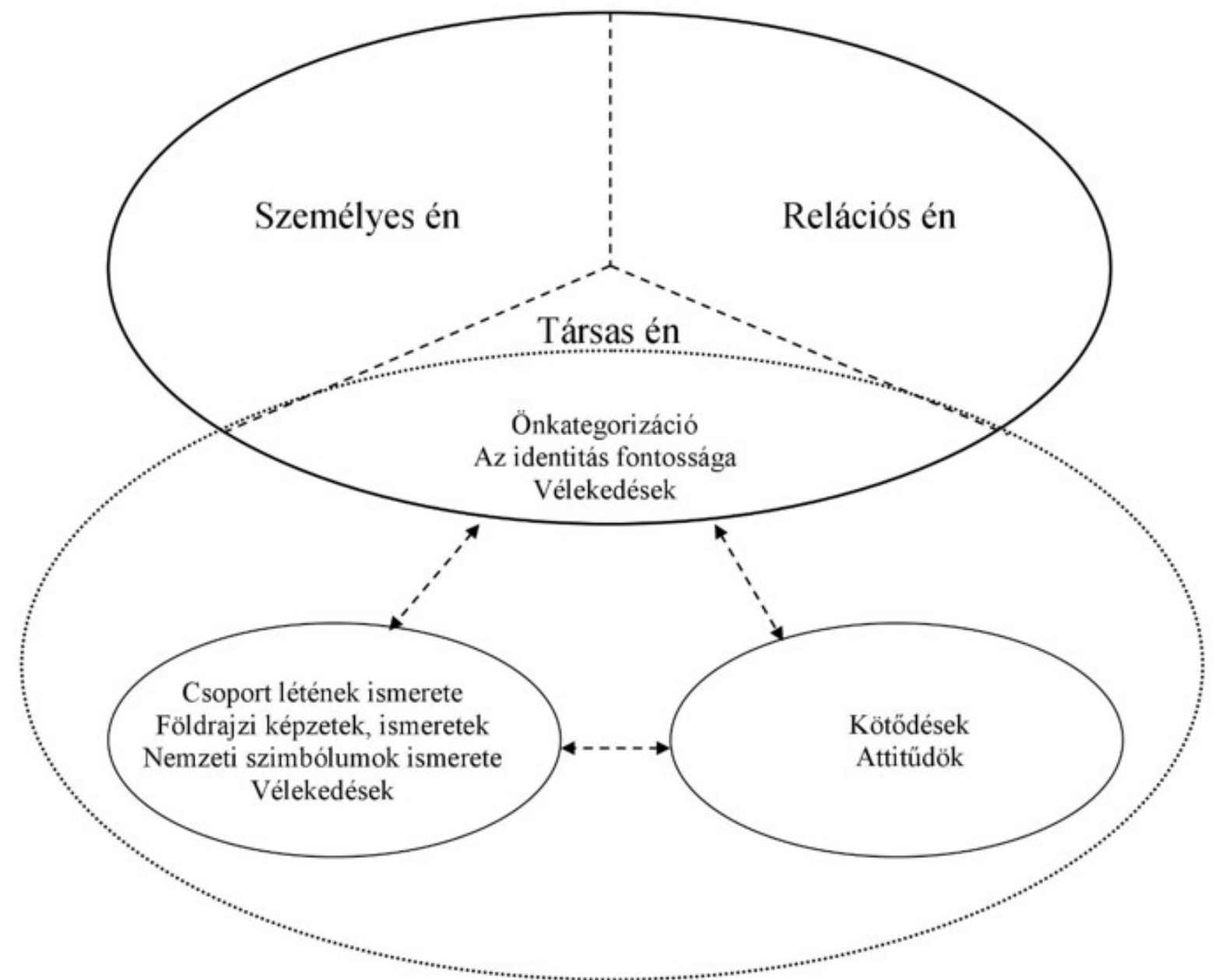

1. ábra: A nemzeti identitás énrendszerben helyet kapó és a pszichikus rendszerben található kognitív és affektív tudáskészletének elemei 


\section{A neveléstudományi kutatások lehetőségei}

A témában folytatható kutatások célkitűzéseit a tantervekben megjelenő fejlesztési feladatok határozzák meg. Az Ember és társadalom múveltségterülethez kapcsolódóan jelenik meg célként a hazafias nevelés és a nemzeti öntudat kialakítása, azaz a nemzeti identitás fejlesztése, valamint ezen keresztül a nyitottság, a tolerancia elősegítése (NAT, 2012). Ugyanakkor a nemzeti identitást az állampolgári kompetencia elemeként is definiálják, így a témával foglalkozó hazai és nemzetközi kutatások is érdeklődnek iránta (Kinyó \& Molnár, 2012).

Az iskolai vizsgálatok elsődleges feladata az lehet, hogy jellemezzék a tanulókat, információt adjanak arról, hogy a nemzeti identitás tudáskészletébe tartozó elemek esetében hogyan alakulnak a tanulók attitúdjei, vélekedései, ismeretei. Így fontos lehet annak tisztázása, hogy a nemzeti identitás erősségének milyen jellemzői vannak az általános iskolások körében. A nemzetközi kutatásokban találunk példákat arra, hogy az említett kor osztály esetében vizsgálták a nemzeti azonosulás erősségét. Az eredmények szerint a gyerekek már hatéves koruktól kezdve egyértelmúen azonosítják magukat egy nemzeti csoport tagjaként, így ettől az életkortól kezdve vizsgálódnak a kutatók. Reizábal, Valencia és Barrett (2004) keresztmetszeti vizsgálatában 6, 9, 12 és 15 évesek azonosulásának erősségét mérte, és nem találtak különbséget az egyes korosztályok között. Clay és Barrett (2011) ezzel szemben erősebb attitűdöket tárt fel a 6-7 évesek körében, mint idősebb társaik esetében. Oppenheimer (2011) 8, 10, 12, 14, 16 éves holland tanulóknál azt találta, hogy a legfiatalabbak (8 és 10 évesek) tanúsították a legerősebb azonosulást, a 12 és 14 évesek gyengébb azonosulást tanúsítottak, míg a 16 éveseknél ismételten erősödés volt megfigyelhető. A nemek esetében erősebb nemzeti azonosulást mutattak ki lányoknál (Mertan, 2011), míg más esetekben nem találtak ilyen különbséget (Oppenheimer, 2011). Az eredmények ellentmondásosak, a kutatók ezzel kapcsolatban felhívják a figyelmet az eltérő kulturális közeg identitáskonstrukcióban betöltött szerepére és ebból fakadóan a nemzeti enkulturáció különböző, országonként el térő mintázatairól beszélnek (Barrett, 2007). Az ellentmondásos eredmények ellenére az énfejlődés jellegzetességei (Rosen \& Patterson, 2011; Harter, 2012) miatt azt feltételezhetjük, hogy a tanulók énképének differenciálódása miatt az attitűdök gyengülése következik be.

A kutatások másik iránya lehet a tanulók nemzeti szimbólumokkal kapcsolatos tudásszintjének jellemzése, mivel az iskolai tananyagban ezek a szimbólumok helyet kapnak. A nemzeti szimbólumokkal kapcsolatban már korábban megállapítottuk, hogy azok a nemzet kollektív emlékezetében jelenlévő narratívák elemei. A nemzeti szimbólumok közös jellemzője, hogy (1) funkciójuk az identitásképzés és a közösség összetartozásának közvetítése, erősítése, a nemzet elképzelt közösségének útjelzői, amelyek kijelölik a mi és ők határvonalat, a közösség határait, kifejezik a közös múltat és jelent (Csepeli, 2002). (2) széles spektrumon mozoghat, hogy mely is meretelemek (pl. személyek, tárgyak, események, szokások, területek, épületek, eszközök) sorolhatók a nemzeti szimbólumok közé. Emellett (3) szimbolikus jelentéstartalommal bírnak, azaz eredeti tartalmuk mellett további, közösségi jelentéssel bírnak, ugyanakkor nyitottak az egyéni interpretációra is (Cohen, 1985/2001; Edensor, 2002). Végezetül (4) érzelmi információkat közvetítenek, melyek a legtöbb esetben pozitív irányúak (például öröm, büszkeség), de negatív érzelmeket is kiválthatnak (például bánat, szégyen) (Bernáth, 2010).

A nemzeti szimbólumok jellemzőinek összefoglalásából kitúnik, hogy annak meghatározása, mely szemé lyek, események, területek vagy alkotások tekinthetők nemzeti szimbólumnak, nem könnyú feladat. A szakiro dalomban sokféle ismeretelem megjelenik a nemzeti szimbólumok között, így például a nemzeti történelemben fontos szerepet kapó személyek és események (Hidegkuti \& Münnich, 2012), a nemzeti jelképek, a fontosabb 
városok (Smith, 1991), de az adott ország esetében jellegzetesnek tartott növények, állatok, tájak, sportok, foglalkozások és kulturális alkotások is funkcionálhatnak nemzeti szimbólumként (Kapitány \& Kapitány, 1998).

A hazai kutatásokban eddig elsősorban azt vizsgálták, hogy a történelmi narratívákban helyet kapó eseményeket hogyan értékelik a tanulók (Kinyó, 2005). Az állampolgári kompetenciával foglalkozó kutatások emellett eddig arra keresték a választ, hogy milyen jellemzői vannak 1-6. évfolyamos diákok társadalmi és állampolgári ismereteinek. Ezekben a tesztekben helyet kapott néhány nemzeti szimbólum (például zászló, címer) (Kinyó, 2015), arra azonban nem alkalmasak, hogy a tanulók szimbólumokkal kapcsolatos teljesítményét megismerjük. Kutatásunkban ezért azt a célt túztük ki, hogy a tanulók tudásszintjének jellemzéséhez használható teszteket dolgozzunk ki. A tanulók nemzeti szimbólumokkal kapcsolatos ismeretei a nemzeti identitás tudáskészletének részét képezik. Kutatásunkban ezért a tanulók nemzeti azonosulásának erősségét is mértük, vizsgáltuk, hogy milyen kapcsolat mutatható ki a jelenségek között. A jelenségek közötti összefüggések keresése elősegíti, hogy jobban megismerjük az iskolai munka hatékonyságát, a tananyag identitáskonstrukcióban játszott szerepét.

\section{Minta és eszközök}

A technológiai fejlődés lehetővé teszi, hogy a pedagógiai folyamatokat IKT-eszközökkel támogassuk. A számítógépalapú mérés (computer-based assessment) a tanulók tudásának értékelését, az azonnali visszajelzést, a diagnosztikus mérést valósítja meg digitális környezetben. A pedagógiai értékelés digitalizálása az említett folyamatok gyorsítása és költséghatékonyabbá tétele mellett újabb lehetőségeket is nyit az értékelés területén. A digitális környezet és az online tér lehetővé teszi olyan területek mérését, amelyeké eddig papír alapon csak nehézkesen volt megoldható (Pásztor-Kovács, Magyar, Hülber, Pásztor, \& Tongori, 2013). A mérésekből származó eredmények és visszajelzések a mindennapi pedagógiai munka segítése mellett a közoktatás fejlesztésének új útját is megnyitják (Csapó, Molnár, Pap-Szigeti, \& R. Tóth, 2009). Végezetül azt is meg kell említeni, hogy az online környezet a tesztkitöltés menetének jobb megértését is lehetővé teszi azáltal, hogy a válaszadói vi selkedés elemeit (például eltöltött idő, kattintások, visszatérések korábbi oldalakra) ún. logfile-okban rögzítik (Csapó, Lőrinczi, \& Molnár, 2012; Zoanetti, 2010).

Az ismertetett előnyök figyelembevételével a számítógépalapú mérés mellett döntöttünk. Vizsgálatunk le bonyolítására 2017 májusában és júniusában került sor az eDia platform segítségével (Molnár \& Csapó, 2013). Az 5. és 6. osztályosok számára kidolgozott tesztfeladatokat és kérdőívet összesen 753 tanuló töltötte ki. 5. évfolyamon 417 fő, 6 . évfolyamon 336 tanuló vett részt vizsgálatunkban. A nemek megoszlása egyenletes a mintában, 19 tanuló esetében ez az adat hiányzott (lásd 1. táblázat).

\begin{tabular}{lrrrr} 
& \multicolumn{1}{c}{ Fiú } & Lány & Hiányzó adat & Összesen \\
\hline 5. évfolyam & 208 & 196 & 13 & 417 \\
6. évfolyam & 160 & 170 & 6 & 336 \\
Összesen (fó) & 368 & 366 & 19 & 753 \\
Összesen (százalék) & $48,88 \%$ & $48,60 \%$ & $2,52 \%$ & $100 \%$ \\
\hline
\end{tabular}

1. táblázat: A tanulók nemi megoszlása az egyes évfolyamokon és a teljes mintában 
A mérés első részében a tanulók a tesztfeladatokat oldották meg, melyek a nemzeti szimbólumokkal kap csolatos ismereteiket mérték. A nemzeti szimbólumok körének meghatározása több lépésben történt a tesztfeladatok elkészítése előtt. Elsőként a szakirodalom alapján meghatároztuk a szóba jöhető szimbólumokat, majd pedagógusokkal folytatott interjúk során szúkítettük a szimbólumok körét azokra, amelyek az általános iskolások esetében szóba jöhetnek. Következő lépésben egy kérdőíves vizsgálat keretei között kérdeztünk meg pedagógusokat arról, hogy az így kiválogatott földrajzi helyszínek, a tárgyi kultúra elemei, történelemi személyek és események véleményük szerint nemzeti szimbólumnak tekinthetők, rendelkeznek-e a szimbólumokra jellemző attribútumokkal (szimbolikus tartalom, pozitív vagy negatív érzelmi töltet). Emellett kértük a résztvevőket, hogy értékeljék a felsorolt szimbólumokat aszerint is, hogy milyen gyakorisággal jelennek meg a peda gógiai munkában. A kérdőíves kutatás eredményeként 51 elemre csökkentettük a listánkat, ebből a kerettantervekhez igazodva kiválogattuk azokat az irodalmi és történelmi személyiségeket, történelmi eseményeket és alkotásokat, amelyek relevánsak a vizsgált korosztály szempontjából (lásd 2. táblázat). A tesztkitöltés alkalmával a tanulóknak felismerést (szelektálást) és felidézést (rövid választ) igénylő feladatokat kellett megoldaniuk.

\begin{tabular}{llll}
\multicolumn{1}{c}{ Személyek } & \multicolumn{1}{c}{$\begin{array}{c}\text { Helyszínek, } \\
\text { területek }\end{array}$} & \multicolumn{1}{c}{$\begin{array}{c}\text { Szellemi és tárgyi } \\
\text { kultúra }\end{array}$} & \multicolumn{1}{c}{$\begin{array}{c}\text { Történelmi } \\
\text { események }\end{array}$} \\
$\begin{array}{l}\text { Géza fejedelem } \\
\text { Szent István } \\
\text { Mátyás király }\end{array}$ & Erdély & tatárjárás \\
Dobó István & Vereckei-hágó & János vitéz & nándorfehérvári csata \\
Petőfi Sándor & Kárpát-medence & Egri csillagok & mohácsi csata \\
Arany János & Szózat & az 1848-49-es forradalom \\
Széchenyi István & Alföld & & és szabadságharc \\
Kossuth Lajos & Ópusztaszer & & Eger 1552-es török \\
Kodály Zoltán & & & ostroma \\
Bartók Béla & & & október 6. \\
& & & augusztus 20.
\end{tabular}

2. táblázat: A tesztben szereplő nemzeti szimbólumok

A szimbólumok mellett a tanulók jellegzetes magyar tájakra vonatkozó ismereteit is mértük. Magyarországra jellemző és nem jellemző tájak képei szerepeltek a tesztben, melyeket előzetesen felnőttekkel értékeltettünk abból a szempontból, hogy mennyire jellemzők Magyarországra, valamint mennyire tartották a képeket vonzónak. Ezen válaszok alapján választottunk ki tíz képet, öt jellegzetes (cseszneki várrom, debreceni és budapesti városrészlet, alföldi és balatoni látkép) és 5 nem jellegzetes magyar tájat (angol falurészlet, hegységet, tundranövényzet, tengerpart és londoni látkép). A tanulóknak a tíz kép esetében azt a feladatot adtuk, hogy döntsék el, Magyarországon készült-e a kép vagy sem. A szimbólumokra és a földrajzi területekre vonatkozó feladatokkal együttesen 48 itemből állt a teszt.

A tesztfeladatok mellett a résztvevők kitöltöttek egy kérdőívet is. Ebben a tanulók szocioökonómiai státuszának jellemzéséhez is gyüjtöttünk adatokat, annak érdekében, hogy megtudjuk, összefüggésbe hozható-e a teszten nyújtott teljesítménnyel. Kértük a tanulókat, hogy adják meg, bizonyos tartós fogyasztási cikkek közül mennyi van a családjuk birtokában (például mobiltelefon, laptop, autó), milyen lakhatási körülmények jellemzik 
otthonukat (például van-e a tanulónak saját szobája), és volt-e lehetőségük az utóbbi évben nyaralásra. Emellett vizsgáltuk a tanulók iskolával kapcsolatos viszonyulását is. Kérdőívünk tartalmazta a nemzeti azonosulás erősségét mérő skála (Strength of Identification Scale, röviden SolS; Barrett, 2007) hazai adaptációját, amely öt attitúdkijelentés segítségével méri a válaszadók nemzeti identitásának erősségét. Ezek a nemzeti közösséggel való azonosulásának mértékére, a nemzeti büszkeségre, a nemzeti identitás fontosságára, a nemzeti érzésre és a nemzeti azonosságtudat belsővé tételének (internalizáció) mértékére vonatkozó állításokat tartalmaznak, melyekre 1-7-ig terjedő Likert-skála segítségével válaszolhattak a tanulók. Érdemes megjegyezni, hogy az utolsó kijelentés fordított volt, azaz a tanulóknak arról kellett véleményt mondaniuk, hogyan éreznék magukat, ha valaki rosszat mondana a magyarokról.

\section{Eredmények}

\section{A teszt müködése}

A teszt megbízhatósága jó, a szimbólumokra vonatkozó feladatok (38 item) esetében a Cronbach-a értéke 0,85, míg a képes földrajzi feladatokkal együtt (48 item) 0,84. Az itemnehézségek vizsgálata alapján megállapítható, hogy a 48 itemes teljes tesztben változatos nehézségú itemek szerepeltek, ugyanakkor több feladat mutatója 0,80-nál nagyobb, azaz a tanulók többségének nem okozott gondot megoldásuk.

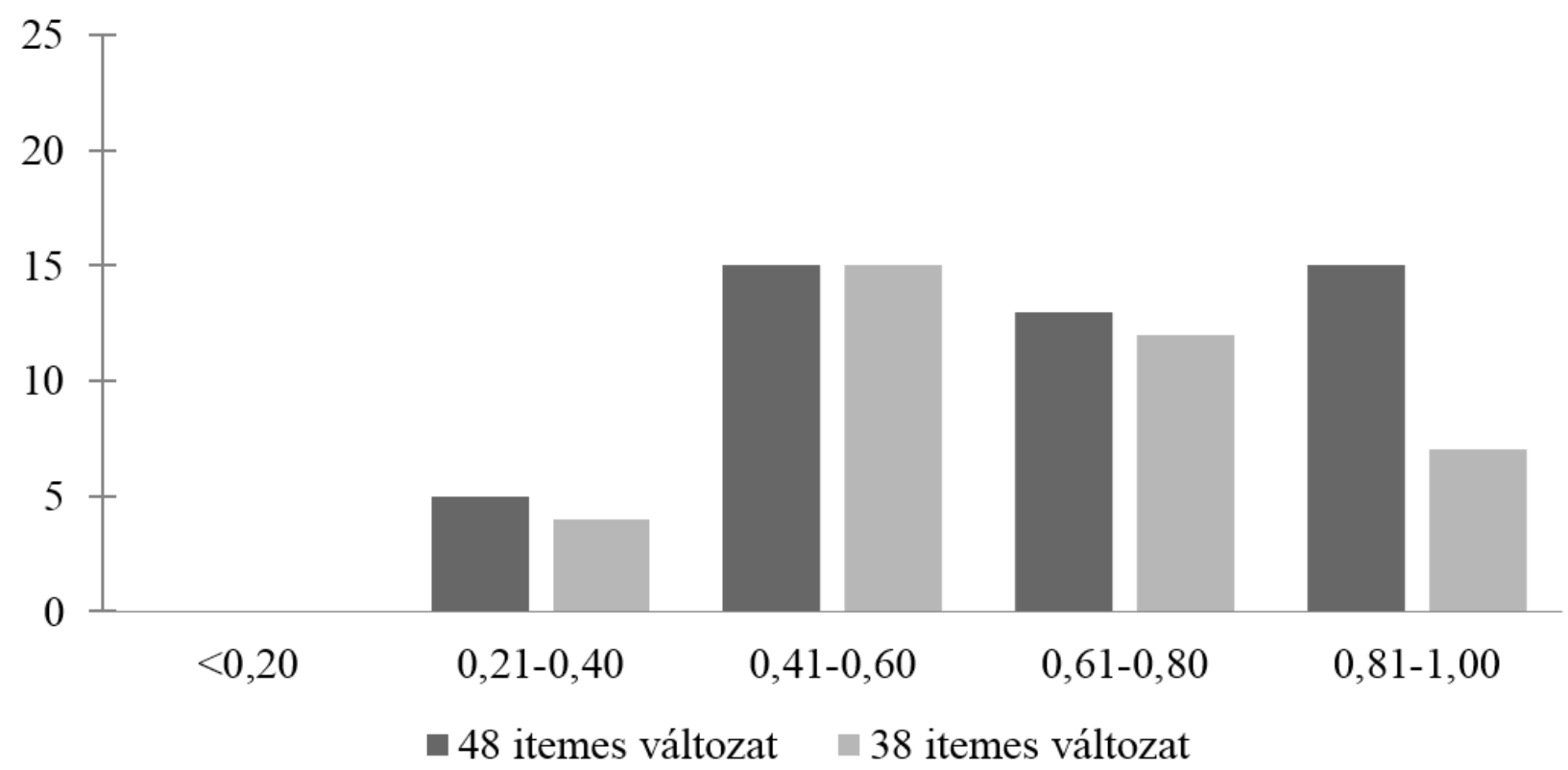

2. ábra: Az itemnehézségek alakulása a szimbólumokra és földrajzi ismeretekre együttesen, valamint csak a szimbólumokra vonatkozó itemek esetében

Megvizsgáltuk az elkülönítésmutatókat is: a 48 item közül tíz esetében nem szignifikáns az értéke. Két item a szimbólumokra vonatkozott, ezekben Bartók Béla portréját kellett felismerniük, és a Székely Bertalan által festett II. Lajos holttestének megtalálása címú képhez kellett a megfelelő eseményt, a mohácsi csatát kiválasztaniuk. A többi nyolc item mind a jellegzetes magyar és nem magyar tájak felismerésére vonatkozott, azaz csak a balatoni látkép és a londoni városrészlet esetében beszélhetünk olyan itemekről, amelyek a tesztünk egészé - 
vel összefüggő ismeretelemeket mérnek. Érdekes eredménynek számít, hogy minden esetben olyan itemek mutatója nem mutatott szignifikáns együttjárást a teszt egészével, amelyek során képek felismerését kértük. Ez arra utalhat, hogy a tanulók tudásrendszerében az általunk mért ismeretek vagy nem kapcsolódnak a teszt által mért tudásegyütteshez, vagy olyan ismereteket mértünk, melyekkel még nem rendelkeznek a tanulók. Az utóbbi feltételezés túnik valószínúbbnek, különösen annak figyelembevételével, hogy a tájakra vonatkozó képeket mi válogattuk össze előzetes kutatómunkánk során. Úgy tűnik, hogy az általunk mérni kívánt ismeretekkel a tanulók még nem rendelkeznek, így ezek mérése még nem lehetséges ebben az életkorban.

A modern tesztelmélet segítségével személy-item térképen tudjuk ábrázolni a tanulók képességszintjének eloszlását, valamint ezzel összefüggésben a feladatok nehézségét (2. ábra).

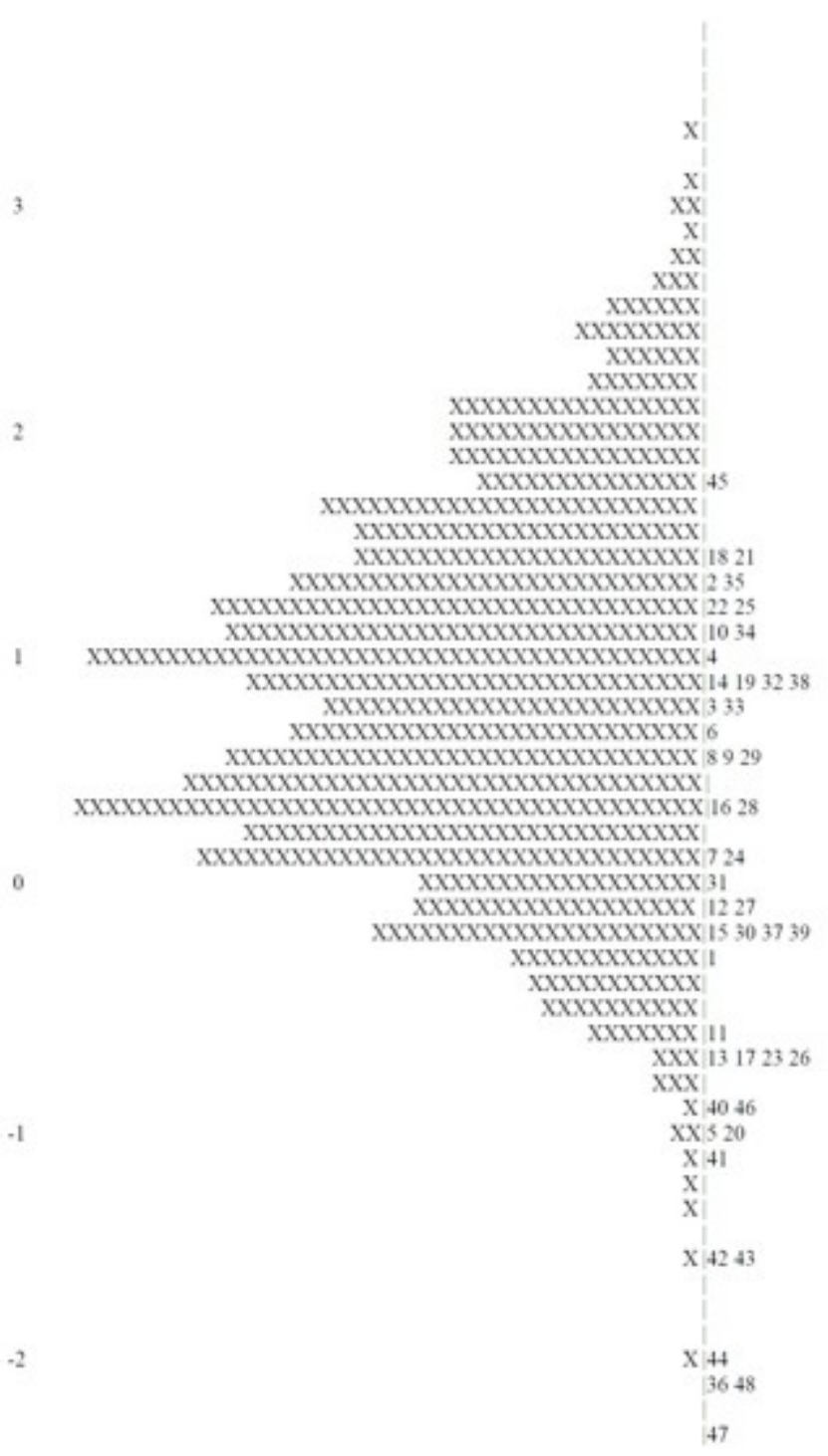

3. ábra: Az itemekhez tartozó személy-item térkép

A tanulók képességszintje széles skálán mozog (-2 és +3 logit között), míg a tesztben szereplő itemek csak a -2 és +2 logit közötti tartományt fedik le. A személy-item térkép alapján megállapítható, hogy az itemek elosz- 
lása egyenletes, valamint széles képességskálát fednek le. A tanulópopuláció eloszlása is egyenletes, azonban azt láthatjuk, hogy a függőleges tengely mentén a két sokaság nem illeszkedik egymáshoz, a kutatásba bevont évfolyamok képességszintje meghaladja a tesztben szereplő feladatokhoz szükséges képességszintet.

Tesztünk továbbfejlesztése, reliabilitásának növelése további itemek bevonásával nem oldható meg, hiszen a tanári vélemények alapján összegyújtött nemzeti szimbólumokat a tantervek alapján válogattuk össze tesz tünkhöz. A feladatok kidolgozásakor a kutatói és szaktanári tapasztalatok szem előtt tartásával határoztuk meg, hogy a tantervekben szereplő ismeretelemeket ráismerés vagy felidézés szintjén kérjük számon a tanulókon. Eredményeink arra utalnak, hogy alábecsültük a tanulók tudásszintjét, ezért a további tesztfejlesztés egyetlen lehetősége, ha a ráismerést kérő feladatokat bizonyos esetekben felidézést kérővé alakítjuk át, amelyek alkalmasak a magasabb képességtartományok lefedésére.

\section{A tesztfeladatokon elért eredmények - évfolyamok és nemek közötti különbségek}

A tanulók átlagosan 31,10 pontot értek el a 48 itemes teszt kitöltése során, azaz 64,78\%-os teljesítményt nyújtottak. Az átlagértékkel összhangban a minimálisan elért pontszám 6 volt, míg több olyan válaszadó is volt, akiknek 47 pontot sikerült szereznie. Ha csak a szimbólumokra vonatkozó feladatokat nézzük, akkor a maximálisan elérhető 38 pontból átlagosan 22,91 pontot gyűjtöttek, azaz 60,28\%-os teljesítményt nyújtottak (3. táblázat). Az itemnehézségnél már szó volt arról, hogy a jellegzetes magyar tájakra vonatkozó feladatok nem kapcsolódtak a teszt egészéhez. Ennek ellenére a tanulók teljesítménye magas volt, a maximálisan szerezhető 10 pontból átlagosan 8,19 pontot értek el, ami 81,89\%-os teljesítménynek felel meg. Ez alapján feltételezhetjük azt is, hogy a dichotóm válaszlehetőségek közül választva a tanulók esetleg több alkalommal tippeléssel oldották meg a feladatokat.

\begin{tabular}{lcr} 
& $\begin{array}{c}\text { Tesztteljesítmény } \\
\text { (\% pont) }\end{array}$ & $\begin{array}{c}\text { Szórás } \\
\text { (\% pont) }\end{array}$ \\
\hline Szimbólumok & 60,28 & 17,98 \\
Jellegzetes magyar tájak & 81,89 & 11,94 \\
Teljes teszt & 64,78 & 15,21 \\
\hline 3. táblázat: A tanulók teljesítményének alakulása a szimbólumokra és a képes földrajzi feladatokra vo-
\end{tabular}

natkozóan

A szórásértékek segítségével további lehetőség nyílik a tanulók teljesítményének jellemzésére. Ezek szerint a tájak felismerése során eredményesebbek voltak a tanulók, míg a szimbólumok esetében jelentősebb különbség mutatkozott az egyes tanulók teljesítményében.

Ha az évfolyamok közötti különbségeket vizsgáljuk, akkor a következőket állapíthatjuk meg: a várakozásoknak megfelelően a 6. osztályosok teljesítménye volt jobb a szimbólumok $(t=-9,39, p=0,000)$ és a jellegzetes magyar tájak felismerése során ( $t=-3,53, p=0,000)$. Nem találtunk különbséget a fiúk és a lányok között a szim bólumok ismeretét illetően, ugyanakkor a magyarországi tájak felismerésében a fiúk szignifikánsan jobb teljesítményt nyújtottak ( $t=3,41, p=0,001)$.

A teszteredmények néhány háttérváltózóval is összefüggésbe hozhatók. A tanulók iskolai teljesítményükkel való elégedettségének mértéke szignifikáns együttjárást mutat a tájak felismerésével $(r=0,13 p=0,000)$ és a szimbólumok ismeretével $(r=0,27, p=0,000)$, ugyanakkor a korrelációs együtthatók értéke alacsonynak mond- 
ható mindkét esetben. A tanulók szociokulturális hátterére vonatkozó kérdések esetében az Országos kompetenciamérésben alkalmazott módszereknek (lásd Balázsi \& Zempléni, 2004) megfelelően jártunk el, azaz a reg resszióanalízis segítségével megvizsgáltuk, melyek alkalmasak a tanulók teljesítményében mutatkozó különbségek magyarázatára. Eredményeink szerint az otthoni számítógépek száma, a tanulók saját szobával való rendelkezése és a nyaralások száma bizonyult olyan tényezőnek, amelyek magyarázó erővel bírnak. A változók azonban együttesen is csak a variancia elenyésző részét, 4\%-át magyarázzák. Ez alapján arra következtethetünk, hogy más változók játszanak szerepet a tanulók tudásszintjében. Kutatásunkban nem vizsgáltuk a részvevők iskoláinak jellemzőit, például hogy a tanárok a nemzeti identitás fejlesztését mennyire tartják fontosnak, ehhez kapcsolódóan milyen módszereket alkalmaznak. Emellett arról sem gyüjtöttünk információkat, hogy a szülők hogyan vélekednek erről a témáról.

\section{Az azonosulás erősségének jellemzői - évfolyamok és nemek közötti különbségek}

Megvizsgáltuk, hogy a nemek illetve a különböző évfolyamok esetében hogyan alakul az egyes kijelentésekkel való egyetértés mértéke. A nemzeti büszkeség, a nemzeti identitás fontossága és a nemzeti érzés esetében találtunk szignifikáns különbséget a két évfolyam tanulói között. Mindhárom esetben a fiatalabb tanulók értettek egyet inkább ezekkel a kijelentésekkel (4. táblázat). A nemek esetében egyik kijelentés esetében sem mutatkozik szignifikáns különbség.

Annak eldöntésére, hogy az adaptált skála tényleg alkalmas-e az említett látens változó mérésére főkomponens-elemzést végeztünk. Az öt attitúdkijelentés együttes KMO-indexe 0,83, így alkalmasak arra, hogy az elemzést elvégezzük. Az eredmények szerint az öt állítás valóban egy faktorba rendeződik, és együttesen a variancia 57,85\%-át magyarázza, így összevont értékük alkalmas arra, hogy a tanulók azonosságtudatának erősségéről képet adjon. Az összevont érték esetében is megvizsgáltuk, milyen életkori és nemi különbségek mutatkoznak. Az életkor esetében szignifikáns különbséget találtunk a tanulócsoportok között: a fiatalabb tanulók tanúsítottak pozitívabb attitúdöket ( $t=2,45, p=0,01)$, míg a nemek esetében nem találtunk különbséget.

\begin{tabular}{|c|c|c|c|c|c|c|c|c|}
\hline & \multicolumn{2}{|c|}{ 5. évfolyam } & \multicolumn{2}{|c|}{ 6. évfolyam } & \multicolumn{2}{|c|}{ Levene } & \multicolumn{2}{|c|}{ Kétmintás t/d } \\
\hline & Átlag & Szórás & Átlag & Szórás & Átlag & Szórás & Átlag & Szórás \\
\hline $\begin{array}{l}\text { Azonosulás } \\
\text { mértéke }\end{array}$ & 6,24 & 1,30 & 6,08 & 1,40 & 1,94 & 0,16 & 1,63 & n.s. \\
\hline Büszkeség & 6,08 & 1,29 & 5,81 & 1,51 & 4,75 & 0,03 & 2,59 & 0,01 \\
\hline $\begin{array}{l}\text { Nemzeti identitás } \\
\text { fontossága }\end{array}$ & 6,01 & 1,31 & 5,72 & 1,49 & 8. 28 & 0,00 & 2,79 & 0,01 \\
\hline Nemzeti érzés & 6,05 & 1,23 & 5,81 & 1,39 & 5,46 & 0.02 & 2,44 & 0,02 \\
\hline Internalizáció & 2,32 & 1,75 & 2,45 & 1,61 & 4,67 & 0,03 & $-1,01$ & n.s. \\
\hline
\end{tabular}

4. táblázat: Évfolyamok közötti különbségek a nemzeti azonosságtudat erősségét mérő kijelentések esetében 
Ezek az eredmények arra utalnak, hogy a fiatalabb tanulók erősebb azonosulást fejeznek ki a nemzeti cso porttal, mint idősebb társaik. Ha megnézzük az egyes kijelentések alakulását is, akkor megállapíthatjuk, hogy abban nem különböznek, mennyire határozottan tekintenek magukra magyarként, vagy milyen mértékben vált az énképük részévé a nemzeti azonosságtudat (lásd internalizáció). Az idősebb tanulók ugyanakkor kevésbé büszkék, kevésbé fontos számukra ez az identitáskategória, és kevésbé tartják jó érzésnek azt, hogy ők is magyarok. A lehetséges magyarázatok közül itt azt érdemes kiemelni, hogy az énfejlódéssel együtt jelentős diffe renciálódás következik be az énképben (lásd Rosen \& Patterson, 2011; Harter, 2012). Egyre több identitáskategóriával gyarapodik a tanulók énrendszere, valamint szerteágazó közegből kapnak visszajelzéseket, differenciálódik önértékelésük. Ennek a differenciálódásnak lehet az eredménye, hogy a korábbi pozitívabb véleményük valamivel kedvezőtlenebbé válik.

Arra is kerestük a választ, hogy a tanulók ismeretei kapcsolatba hozhatók-e attitűdjeikkel. A SolS kijelentései és a tesztpontszámok között szignifikáns korrelációs kapcsolatok mutatkoznak, azonban az együtthatók értéke alacsony a teljes mintán a szimbólumok $(r=0,17, p=0,000)$ és a tájak felismerése $(r=0,15, p=0,000)$ eseté ben. Amennyiben az egyes évfolyamokat vizsgáljuk, eltérő kép rajzolódik ki. Az 5. osztályos diákok azonosulásának erőssége továbbra is szignifikánsan korrelál a szimbólumok ismeretével $(r=0,24, p<0,001)$ és a tájak felismerésével $(r=0,21, p=0,000)$. A 6. évfolyamosok esetében összefüggés továbbra is fennáll $(r=0,16, p=0,05)$. Z-próba segítségével összehasonlítottuk az együtthatókat, az elemzés szerint nincs szignifikáns különbség az együtthatók között, így nem jelenthetjük ki, hogy gyengül a változók közötti kapcsolat. Ugyanakkor érdekes eredménynek számít, hogy a tájak felismerése csak 5. évfolyamon mutat szignifikáns korrelációs kapcsolatot az azonosulás erősségével. Ezzel szemben a szimbólumok ismerete és az iskolai teljesítménnyel való elégedettség esetében szintén nincsen szignifikáns különbség az együtt járás mértékében.

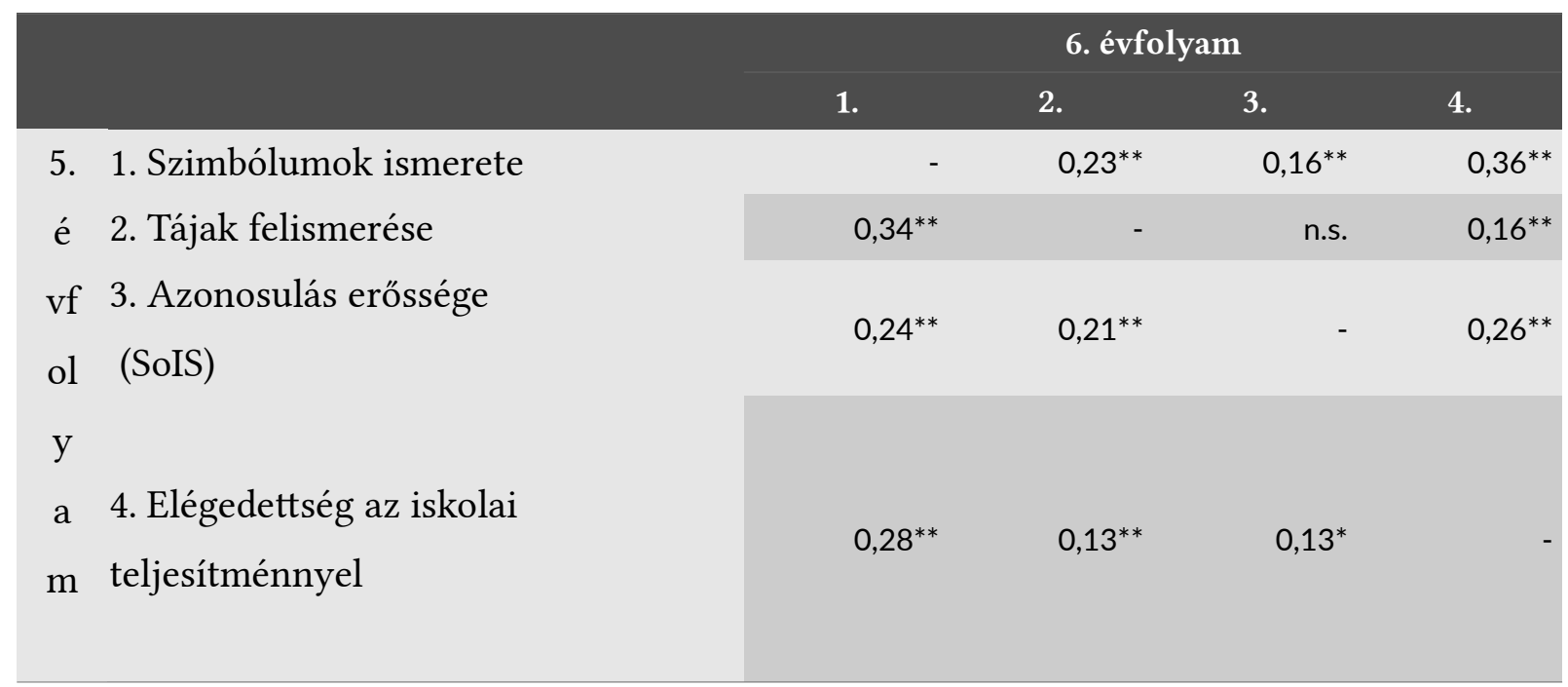

5. táblázat: A nemzeti azonosságtudat mérésére használt kijelentések összefüggései a pontszámokkal Megjegyzés: * $p<0,05$ szinten szignifikáns kapcsolat, ${ }^{* *} p<0,01$ szinten szignifikáns kapcsolat

Ezek az eredmények arra utalnak, hogy a tanulók ismeretei ebben az életkorban nem állnak szoros kapcsolatban a nemzeti azonosulás erősségével, azaz nem a nemzeti identitás erősségével hozható összefüggésbe, hogy melyik tanuló mennyi szimbólumnak tekinthető történelmi személyt, eseményt, kulturális elemet vagy földrajzi területet ismer. 


\section{Tesztviselkedés}

A tesztviselkedést gyakran elemzik a vonatkozó adatok közül a teljes teszttel, illetve az egyes feladatokkal töltött idővel, valamint ezeknek a kitöltők teljesítményével való kapcsolatával. Goldhammer, Naumann és Greiff (2015) eredményei szerint egyéni szinten a kitöltésre fordított idő és a feladat megoldottsága negatív együttjárást mutat, azaz akik több időt töltöttek a feladatokkal, gyengébb teljesítményt nyújtottak. Az összefüggés erősségét befolyásolta, hogy milyen képességszinttel rendelkezett a kitöltő, és milyen nehézségú volt a megol dott feladat.

A PISA olvasásvizsgálataiban hasonlóan negatív együttjárást tártak fel a feladatmegoldás sikeressége és a feladattal töltött idő között. A magasabb képességszinttel rendelkező tanulóknak rövidebb volt a reakcióidejük (azaz hamarabb kezdték el a feladat megoldását), mint az alacsonyabb képességszinttel rendelkező társaiknak. Éppen ezért az egyik lehetséges magyarázat a feltárt összefüggésre, hogy az egyéni különbségek, azon belül is a képesség begyakorlottsága az egyik fontos tényező, ami kontrollálja a feladatokkal töltött időt. A teszttel töltött időre a kitöltők motivációjának egyik indikátoraként is tekinthetnénk, amely esetben pozitív együttjárást feltételezhetnénk a változók között. Az eredmények azonban kimutatták, hogy a feladatok nehézsége sokkal inkább befolyásolja az időt, mint más változó. A könnyú feladatok automatikus reakciókat, gyors feladatmegoldást tesznek lehetővé, így ezen esetekben negatív korreláció áll fenn az idő és a teljesítmény között. A nehéz feladatok esetében azonban az együttjárás megfordul, az összetettebb feladatok megoldása több időt igényel a kitöltőktól (OECD, 2015).

Hazai kutatások tudásszintmérő tesztek esetében is megerősítették, hogy a feladatok megoldására fordított idő az itemek nehézségével függ össze, valamint azok tesztben elfoglalt helyével: a teszt elején elhelyezkedő feladatokkal a tanulók több időt töltöttek (Vidákovich, 2014). Az 1-6. osztályosok állampolgári ismereteit mérő tesztek eredményeinek elemzése arra mutatott rá, hogy az alsóbb évfolyamos tanulóknak volt szüksége több időre a kitöltésre, ami utalhat a képességszintbeli, valamint a számítógépes jártasságban megmutatkozó különbségekre is. Ezzel összhangban az idősebb tanulók fordítottak kevesebb időt a feladatok megoldására. A tesztre kevés idôt fordító tanulók esetében pozitív összefüggés mutatkozott a képességparaméter és a teszttel töltött idő esetében (Kinyó \& Dancs, 2015).

Az online tesztkitöltés lehetővé tette, hogy információkat gyújtsünk a tanulók tesztviselkedéséről. Minden tanuló esetében rendelkezésünkre állt a tesztfeladatok, valamint a tesztfeladatok és a kérdőív együttes kitöltéséhez szükséges idő. A feladatok kitöltése átlagosan 10,5 percet (pontosan 631,36 mp-t) igényelt (szórás: 3,41 perc, pontosan 205,88 mp) igényelt a tanulóktól, ugyanakkor a szórásérték segítségével azt is megállapíthatjuk, hogy a tanulók 41\%-ának 6,75 és 13,95 perc (405,48 és 837,24 mp) közötti időre volt szüksége, hogy válaszoljon kérdéseinkre.

A tesztre fordított idő és az elért eredmény között nem találtunk szignifikáns kapcsolatot a teljes mintán. A lányok és a fiúk között szignifikáns különbség mutatkozott ( $t=-3,54, p=0,000)$, a lányok átlagosan 52 másod perccel több időt fordítottak a kitöltésre. Az évfolyamok esetében az 5. osztályosok átlagosan 40 másodperccel több időt töltöttek a feladatmegoldással ( $t=2,78, p=0,006)$. Megvizsgáltuk az egyes feladatokra felhasznált idő és a teljesítmény kapcsolatát is, a várakozásokkal ellentétben azonban egy eset kivételével nem találtunk összefüggést a feladatra fordított idő és a megoldottság között.

A kitöltéshez szükséges idő esetében jelentős különbségek észlelhetők a tanulók között, melyek több tényezővel is indokolhatók. Egyrészt a tanulók motiváltsága eltérő lehetett, különbözőképpen álltak a kitöltés- 
hez. Arról nem gyűjtöttünk információt, hogyan érezték magukat a kitöltés során, az iskolába járás szeretetéről viszont kérdeztük a tanulókat. Az elemzések szerint pozitív együttjárás tapasztalható a kitöltésre fordított idő $(r=0,26, p=0,000)$, valamint az iskolába járás kedveltsége között. Ez az eredmény arra enged következtetni, hogy azok a tanulók, akik pozitívan viszonyulnak az iskolához, a kitöltésre is több időt szántak, míg akik kevés bé szeretnek iskolába járni, kevesebb időt töltöttek el a teszt és a kérdőív kitöltésével. Évfolyamok szerinti bontásban azonban ez az összefüggés eltünik, és sem 5. sem 6. évfolyamosok esetében nem mutatható ki ez az a kapcsolat a változók között.

Szignifikáns egyéni különbségeket feltételezhetünk a tanulók számítógépes jártasságában is. Háttérkérdőívünkben a szülői háztartásban található eszközök számával kapcsolatban is gyüjtöttünk információkat. A válaszadók 11\%-ának nincsen otthon számítógépe, míg 34,8\%-nak egy, 30,3\%-nak két, 23,9\%-nak három számítógép is van a birtokában. A mobiltelefonok jóval elterjedtebbek a háztartásokban: mindössze a válaszadók családjának 0,8\%-ának nincsen ilyen eszköze, míg 89,9\% esetében a háztartásban legalább három ilyen eszköz is található. Feltételezésünk igazolásához a rendelkezésünkre álló időadatokat hasonlítottuk össze az otthoni számítógépek száma szerint képzett csoportokban. A varianciaanalízis eredményei szerint sem a feladatokra, sem a teljes kitöltésre fordított idő esetében nincsen szignifikáns különbség az egyes részminták között. Ezen eredmények alapján kijelenthetjük, hogy mérésünk esetében nem a tanulók számítógépes jártasságában mutatkozó különbségek állnak a kitöltéshez szükséges idők esetében tapasztalható különbségek mögött.

Megvizsgáltuk azt is, hogy az átlagnál több vagy kevesebb időt teszteléssel töltő tanulók teljesítményében milyen különbségek vannak. Az átlagos időtől egy-egy szórásnyi értékre elhelyezkedő időadatokat felhasználva 3 csoportot hoztunk létre a 6,75 perc $(405,48)$ és 13,95 perc $(837,24 \mathrm{mp})$ határokat felhasználva. A variancia analízis szerint a legkevesebb időt töltők eredménye szignifikánsan különbözik az átlagos vagy áltagosnál több idő alatt megoldókétól. A legjobb teljesítményt azok nyújtották, akik átlagos idő alatt oldották meg a tesztet, míg a leggyengébb teljesítményt a kevés időráfordítással megoldók érték el. A három csoport esetében azt is megvizsgáltuk, hogy tapasztalható-e különbség az iskolába járás kedveltségében, eredményeink szerint azonban ebben a tekintetben nincsen eltérés a csoportok között.

\begin{tabular}{|c|c|c|c|c|c|}
\hline & Létszám & $\begin{array}{c}\text { Átlagos } \\
\text { teljesítmény }\end{array}$ & Szórás & $\begin{array}{c}\text { Iskolába járás } \\
\text { szeretete }\end{array}$ & Szórás \\
\hline$<405,48 \mathrm{mp}$ & 76 & 29,13 & 9,60 & 3,01 & 1,11 \\
\hline $405,48 \mathrm{mp}<$ és $<837,24 \mathrm{mp}$ & 571 & 31,35 & 7,05 & 3,03 & 0,98 \\
\hline $837,24 \mathrm{mp}<$ & 106 & 30,05 & 7,17 & 3,16 & 1,00 \\
\hline
\end{tabular}

6. táblázat: A szórásértékek felhasználásával létrehozott három csoport létszáma, valamint átlagos teljesitménye

\section{Összefoglalás}

Bemutatott kutatásunk a tanulók nemzeti szimbólumokkal kapcsolatos tudásszintjét mérő tesztünk első adat felvételének eredményeit ismerteti. Ezek szerint a kidolgozott teszt megbízhatónak bizonyult, alkalmas a tanulók tudásszintjének jellemzésére, ugyanakkor a teszt mutatói alapján elmondható, hogy a jellegzetes magyar tájak felismerését mérő feladatok nem kapcsolódtak tesztünk egészéhez. Feltételezhetjük, hogy a tájak felismerése bonyolult ismeretegyüttest igényel, ami a magyar és nem magyar tájakkal kapcsolatos tapasztalatok 
összegzéseként jön létre. Eredményeink arra utalnak, hogy a vizsgált évfolyamokon a tanulók még nem rendelkeznek ezekkel az ismeretekkel. A tesztfejlesztés további lépése lehet a teszt megbízhatóságának növelése. A mért tudáskészlet speciális, definiálása, elemeinek meghatározása több lépésben történt, így itemek elhagyásával nem tudunk rajta javítani. Az itemek követelményeinek átalakítása, a ráismerést kérő feladatok felidézést igénylővé alakításában látjuk azt a lehetőséget, amelynek segítségével növelni tudjuk a továbbiakban tesztünk reliabilitását.

Eredményeink szerint a 6. évfolyamos tanulók szignifikánsan jobb teljesítményt nyújtottak a teszten, mint fiatalabb társaik. A nemek esetében csak a tájak felismerésével kapcsolatban találtunk különbséget: a fiúk teljesítménye volt jobb. A tanulók teszteredményének csak nagyon kis részét magyarázza szocioökonómiai státuszuk, így a nemzeti szimbólumokkal kapcsolatos teljesítmény esetében nem jelenthetjük ki, hogy a tanulók családi hátterének ezen tényezője lenne a felelős a teljesítménykülönbségekért. Ennek ellenére a család fontos szerepet játszik a nemzeti enkulturációban (lásd Barrett, 2007), ebből adódóan feltételezhetjük, hogy hatással van a nemzeti szimbólumok elsajátítására is. Mivel azonban a szimbólumok az iskolai tananyagban is megjelennek, az is valószínú, hogy ez a hatás csak az iskola megkezdése előtt vagy az iskolába lépéskor érvényesülhet. $A$ tanulók közötti különbségek forrását a vizsgált évfolyamokon más tényezőkben kell keresnünk. A családi háttér esetében a szülők nemzeti identitása, ezzel kapcsolatos vélekedéseik lehetnek olyan tényezők, amelyek vizs gálata indokolt lehet. Az iskola esetében a pedagógusok vélekedései, pedagógiai gyakorlata lehetnek olyan változók, amelyek hatással lehetnek a tanulókra, így ezek feltérképezése lehet a továbblépés másik lehetősége.

A tanulók tudásszintjének jellemzése mellett kutatásunkban arra is kerestük a választ, hogy milyen válto zókkal hozható összefüggésbe a teljesítmény. Mind a tájak felismerése, mind a szimbólumok ismerete együttjárást mutat azzal, hogy a tanulók mennyire elégedettek iskolai teljesítményükkel. Korábban már volt szó az iskolán kívüli hatások szerepéről, ez az eredmény azonban azt erősíti meg, hogy az iskolai hatások sem elhanyagolhatók. Megvizsgáltuk a teljesítmény és a kitöltésre szánt idő kapcsolatát is: az eredmények szerint a teljes teszten nyújtott teljesítmény a kitöltés során nem függött össze a kitöltésre fordított idővel. Feladatszinten is megvizsgáltuk a kapcsolatot, nem találtunk azonban kapcsolatot a feladatokra fordított idő és a megoldottság között a vizsgált évfolyamokon. A rendelkezésre álló IKT eszközök szerint sem találtunk különbségeket, ami alapján nem a jártasságbeli különbségeknek tulajdonítottuk az időadatokban megmutatkozó nagy eltéréseket.

Pozitív kapcsolatot találtunk az iskolába járás kedveltsége mint az iskolához fúződő általános viszonyulás indikátora és a tesztidő között: a kitöltésre több időt fordítók pozitívabb attitűdöket táplálnak az iskola iránt is. Megvizsgáltuk a kitöltésre kevés, átlagos és az átlagosnál több időt fordítókat is: a várakozásoknak megfelelő en a legkevesebb időráfordítással dolgozók eredménye lett a leggyengébb. Feltételeztük, hogy az idő és az is kola kedveltsége közötti kapcsolat okán különbség lesz a csoportok között az iskolához való viszonyulásban. Várakozásainkkal ellentétben azonban nem találtunk eltérést a csoportok attitúdjeiben. Ez utóbbi eredmény arra utal, hogy a csoportok közötti teljesítménykülönbséget nem feltétlenül tulajdoníthatjuk a kitöltők eltérő motiváltságának. Feltételezhetjük, hogy a tanulók egyéb képességeiben (például a szövegértésben) megmutatkozó különbségek is felelősek az időadatokban tapasztalható eltérésekért.

A szakirodalomi várakozásokkal összhangban (Oppenheimer, 2011) az azonosulás erősségéről elmondható, hogy erősebben van jelen a fiatalabb tanulóknál. Ezt az eredményt úgy interpretálhatjuk, hogy a tanulók nem zeti identitása gyengül és kevésbé fontos számukra, ez azonban nem az enkulturációs folyamat zavarát jelezi, hanem a tanulók énfejlődésének velejárója. Arról nem gyüjtöttünk információt, hogy milyen más identitáskategóriákkal (például nemi, lakóhelyi, életkori stb.) jellemezhetők a tanulók, és ezek számukra milyen fontossággal 
bírnak. Elképzelhető, hogy a vizsgált életkorban - a serdülőkor kezdetén - jelentkező változások átformálják a tanulók személyiségét, énrendszerét, és egészen új együttállásokat hoznak létre. A továbbiakban ezért érde mes lenne más életkorokra is kiterjeszteni a vizsgálatokat, és feltérképezni, hogy a serdülőkorban, valamint fiatalabb tanulók körében milyen változások következnek be.

A tanulók ismeretei és nemzeti azonosulásának erőssége között 5. és 6. évfolyamon is találtunk szignifikáns korrelációs kapcsolatot, amely elemzésünk szerint azonos erősségú a két évfolyam esetében. Ez az összefüggés indirekt módon arra enged következtetni, hogy a két vizsgált jelenség feltételezhetően ugyanannak a hipo tetikus konstruktumnak, a nemzeti identitás tágan értelmezett tudáskészletének eleme. További kutatások szükségesek a változók közötti kapcsolat pontos értelmezéséhez. Esetünkben a tanulók először a tesztfeladatokat oldották meg, majd a kérdőív kérdéseire válaszoltak. Elképzelhető, hogy a kitöltési sorrendnek hatása volt a válaszokra, például a szimbólumokra vonatkozó feladatok mozgósították a tanulók attitúdjeit vagy érzelmeit, amelyek pozitívabb attitúdök formájában jelentek meg az azonosulás erősségét mérő kérdéseknél. A továbblépés egyik lehetősége lehet egy olyan kutatás lebonyolítása, ahol az egyik csoport a már ismertetett sorrendben tölti ki a kérdéseket, míg a másik csoport fordított sorrendben, ezzel ellenőrizhetővé válik, hogy a fel tett kérdések sorrendje, vagyis az egyes tudáselemek aktiválása hatással van-e az eredmények alakulására.

Összefoglalóan megállapíthatjuk, hogy az 5. és 6. osztályos tanulóknak kidolgozott tudásszintmérő tesztünk alkalmas a diákok tudásszintjének jellemzésére. Az eredmények alapján úgy tűnik, jelentős különbségek van nak a tanulók között, de általában véve jól teljesítettek, és a kerettantervekben megjelenő nemzeti szimbólu mokat legalább felismerés szinten, de elsajátították. Megvizsgáltuk a nemzeti identitás fontosságát mérő attitűdkijelentések és a teszteredmények közötti kapcsolatot is: úgy túnik, hogy a vizsgált életkorban nincsen változás, ugyanolyan erősségú kapcsolat mutatható ki 5. és 6. évfolyamon. Ugyanakkor fontos hangsúlyozni, hogy a feltárt korrelációs együtthatók értéke alacsony, amit a következőképpen magyarázhatunk: az említett ismeretelemek egyre gyakrabban kerülnek elő az iskolai tananyagban (például irodalom, történelem, földrajz), emiatt többet találkoznak és foglalkoznak ezekkel a tanulók. Emiatt az elemek kapcsolata a nemzeti identitással gyengül, és immáron nem a nemzeti lét kifejezőiként gondolnak rájuk a tanulók, hanem mint megtanulandó elemekre, amelyeket az iskolában kérnek számon rajtuk. Annak eldöntésére, hogy pontosan milyen változások következnek be, a vizsgálatok további szélesítésére, fiatalabb tanulók bevonására van szükség a jövőben.

\section{Irodalom}

1. Anderson, B. (1983/2006). Elképzelt közösségek. Budapest: L'Harmattan: Atelier.

2. Assmann, J. (1999). A kulturális emlékezet. Budapest: Atlantisz Könyvkiadó.

3. Balázsi, I. \& Zempléni, A. (2004). A hozottérték-index és a hozzáadott pedagógiai érték számítása a 2003-as kompetenciamérésben. Új Pedagógiai Szemle, 54.(12.), 36-50.

4. Barrett, M., Wilson, H., \& Lyons, E. (2003). The development of national ingroup bias: English children's attributions of characteristics to English, American and German people. British Journal of Developmental Psychology, 21.(2.), 193-220.

5. Barrett, M. (2007). Children's knowledge, beliefs and feelings about nations and national groups. Hove: Psychology Press.

6. Bennett, M. \& Sani, F. (2004). Introduction: Children and social identity. In Bennett, M. \& Sani, F. (Eds.), The Development of the Social Self. (pp. 1-26.) Hove \& New York: Psychology Press.

7. Bernáth, Á. (2010). A történelmi múlt megörzésének természetes formái avagy a kollektív emlékezet és a társas reprezentációk. In Münnich, Á. \& Hunyady, Gy. (Eds.), A nemzeti emlékezet vizsgálatának pszichológiai szempontjai (pp. 117-134). Budapest: ELTE Eötvös Kiadó. 
8. Brewer, M. B. \& Gardner, W. (1996). Who is this "we "? Levels of collective identity and self representations. Journal of Personality and Social Psychology, 71. (1.), 83-93.

9. Clay, D. \& Barrett, M. (2011). National identifications and attitudes towards a "traditional enemy" nation among English children. European Journal of Developmental Psychology, 8. 25-42.

10. Cohen, A. P. (1985/2001). The Symbolic Construction of Community. London \& New York: Routledge.

11. Csapó, B. (2003). Oktatás az információs társdalom számára. Magyar Tudomány, 47.(12.), 1478-1485.

12. Csapó B., Molnár Gy., Pap-Szigeti, R., \& R. Tóth, K. (2009). A mérés-értékelés új tendenciái: a papír és számítógép alapú tesztelés összehasonlító vizsgálatai általános iskolás, illetve főiskolás diákok körében. In Perjés, I. \& Kozma T. (Eds.), Új kutatások a neveléstudományokban. Hatékony tudomány, pedagógiai kultúra, sikeres iskola (pp. 99-108). Budapest: Magyar Tudományos Akadémia.

13. Csapó, B., Lőrincz, A., \& Molnár, Gy. (2012). Innovative Assessment Technologies in Educational Games Designed for Young Students. In Ifenthaler, D., Eseryel, D., \& Ge, X. (Eds.), Assessment in gamebased learning: foundations, innovations, and perspectives. (pp. 235-254). New York: Springer.

14. Csepeli, Gy. (2002). A nagyvilágon e kívül... Nemzeti tudat és érzésvilág Magyarországon 1970-2002. Budapest: Jószöveg Műhely Kiadó.

15. Csepeli, Gy., Örkény, A., Székelyi, M., \& Poór, J. (2004). Nemzeti identitás Magyarországon az ezredfordulón. In Kolosi T., Tóth I. Gy., \& Vukovich Gy. (2004). Társadalmi Riport 2004 (pp. 471-483). Budapest: TÁRKI.

16. Dancs, K. (2016). Kultúra - iskola - nemzeti azonosságtudat. A nemzeti identitás értelmezése és vizsgálatának lehetőségei általános iskolások körében. Magyar Pedagógia, 116.(4.), 403-425.

17. Davis, S. C. (2007). Children's implicit and explicit ethnic attitudes, ethnic group identification and self-esteem. International Journal of Behavioral Development, 31.(5.), 514-525.

18. Edensor, T. (2002). National Identity, Popular Culture and Everyday Life. Oxford \& New York: Berg.

19. Goldhammer, F., Naumann, J., \& Greiff, S. (2015). More is not Always Better: The Relation between Item Response and Item Response Time in Raven's Matrices. Journal of Intelligence, 3.(1.), 21-40.

20. Harter, S. (2012). Emerging self processess during childhood and adolescence. In Leary, M. \& Tangney, J. (Eds.). Handbook of self and identity (pp. 680-715). New York: Guilford Press.

21. Hidegkuti, I. \& Münnich, Á. (2012). Nemzeti emlékezethelyek kapcsolatainak jellemzése. In Kovács, J. \& Münnich, Á. (Eds.), Nemzeti emlékezethelyek: attitüdök, reprezentációk, élmények, funkciók, struktúrák (pp. 9-32). Debrecen: Debreceni Egyetemi Kiadó.

22. Kapitány, Á. \& Kapitány, G. (1998). Nemzeti és politikai szimbólumok változásai a 20. században. In Voigt, V. (Ed.), A magyar jelrendszerek évszázadai (pp. 121-150). Budapest: Magyar Szemiotikai Társaság.

23. Kinyó, L. (2005). A magyar történelmi események, korszakok megítélése 7. és 11. évfolyamos tanulók körében végzett kérdőíves vizsgálat eredményei alapján. Magyar Pedagógia, 105.(4.), 409-432.

24. Kinyó L. (2015). A társadalmi és állampolgári ismeretek online vizsgálata. In Csapó, B. \& Zsolnai, A. (Eds.). Online diagnosztikus mérések az iskola kezdő szakaszában (pp. 97-122). Budapest: Oktatáskutató és Fejlesztő Intézet.

25. Kinyó, L. \& Dancs, K. (2015). 7-12 éves tanulók állampolgári tudásának online vizsgálata és a teljesítmények összefüggése az adatfelvétel során gyűjtött tanulói szintú interakciós adatokkal. Magyar Pedagógia, 115.(2.), 93-113.

26. Kinyó, L. \& Molnár, E. K. (2012). Történelem és társadalomismeret, állampolgári kompetenciák. In Csapó, B. (Ed.), Mérlegen a magyar iskola (pp. 289-326). Budapest: Nemzeti Tankönyvkiadó.

27. László, J. (2012). Történelemtörténetek: bevezetés a narratív pszichológiába. Budapest: Akadémiai Kiadó.

28. Mertan, B. (2011). Children's perception of national identity and in-group/out-group attitudes: Turkish-Cypriot school children. European Journal of Developmental Psychology. 8.(1.), 74-86. 
29. Molnár, Gy. \& Csapó, B. (2013). Az eDia online diagnosztikus mérési rendszer. In Józsa, K. \& Fejes, J. B. (Eds.), XI. Pedagógiai Értékelési Konferencia. Program - Előadás-összefoglalók (pp. 82). Szeged: Szegedi Tudományegyetem.

30. NAT (2012). Nemzeti alaptanterv, 110/2012. kormányrendelet

31. Nora, P. (2009). Emlékezet és történelem között. Válogatott tanulmányok. Budapest: Napvilág Kiadó.

32. OECD (2015). Students, Computers and Learning: Making the Connection, PISA, OECD Publishing. Retrieved from https://static.rasset.ie/documents/news/oecd-report-on-technology-in-education.pdf

33. Oppenheimer, L. (2011). National identification of Dutch youth: An exploratory study. Journal of Adolescence, 34. 445-453.

34. Oyserman, D., Elmore, K., \& Smith, G. (2012). Self, Self-Concept, and Identity. In Leary, M. R. \& Tangney, J. P (Eds), Handbook of Self and Identity. Second edition (pp. 69-104). New York: Guilford Press

35. Pataki, F. (2008). Az „eltűnt én” nyomában. Magyar Pszichológiai Szemle, 63.(3.), 409-470.

36. Pataki, F. (2011). Stabilitás és változás az én-rendszerben. Magyar Pszichológiai Szemle, 66.(2.), 229268.

37. Pásztor-Kovács A., Magyar A., Hülber L., Pásztor A., \& Tongori Á. (2013). Áttérés online tesztelésre - a mérés-értékelés új dimenziói. Iskolakultúra, 23.(11.), 86-100.

38. Reizábal, L., Valencia, J., \& Barrett, M. (2004). National Identifications and Attitudes to National Ingroups and Outgroups amongst Children living in the Basque Country. Infant and Child Development, 13.(1.), $1-20$.

39. Renan, R. (1995). Mi a nemzet? In Bretter, Z. \& Deák, Á. (Eds.), Eszmék a politikában: a nacionalizmus (pp. 171-187). Pécs: Tanulmány Kiadó.

40. Rosen, L. H. \& Patterson, M. M. (2011). The Self and Identity. In Underwood, M. K. \& Rosen, L. H. (Eds.), Social Development. Relationships in Infancy, Childhood and Adolescence. (pp. 73-100.) New York: The Guildford Press.

41. Sedikides, C., Gaertner, L., \& O’Mara, E. M. (2011). Individual Self, Relational Self, Collective Self: Hierarchical Ordering of the Tripartite Self. Psychological Studies, 56.(1.), 98-107.

42. Smith, A. (1991). National identity. London: Penguin Books.

43. Smith, A. D. (2009): Ethno-symbolism and nationalism. A cultural approach. London \& New York: Rutledge.

44. Stryker, S. \& Burke, P. J. (2000). The Past, Present, and Future of an Identity Theory. Social Psychology Quarterly, 63.(4.), 284-297.

45. Swann Jr., W. B. \& Bosson, J, K. (2011). Self and Identity. In Fiske, S. T., Gilbert, D. T., \& Lindzey, G. (Eds.), Handbook of Social Psychology. Fifth Edition (pp. 589-628). Hoboken, New Jersey: John Wiley \& Sons.

46. Szabó, I. (2004). Kollektív identitásminták a politikai szocializációban. Educatio, 13.(4.), 551-566.

47. Szabó, I. (2010). Nemzeti identitás és politikai szocializáció. Új Ifjúsági Szemle, 8.(1.), 75-98.

48. Tajfel, H. \& Turner, J. C. (1979). An Integrative Theory of Intergroup Conflict. In Austin, W. G. \& Worchel, S. (Eds.), The Social Psychology of Intergroup Relation (pp. 33-47). Monterey: Brooks-Cole, Monterey 33-47.

49. Vidákovich, T. (2014). Students' task response times and task solving efficiency on online foreign language vocabulary tests. In Korom E. \& Pásztor, A. (Eds.), PÉK 2014. XII. Pedagógiai Értékelési Konferencia. Program; Elöadás-összefoglalók (pp. 127). Szeged: SZTE BTK Neveléstudományi Doktori Iskola.

50. Vigolens, V. L., Schwartz, S. J., \& Luyckx, K. (2011). Introduction: Toward an Integrative View of Identity. In Schwartz, S. J., Luyckx, K., \& Vignoles, V. L. (Eds.), Handbook of Identity Theory and Research (pp. 1-30). New York: Springer. 
51. Zoanetti, N. (2010). Interactive computer based assessment tasks: How problem-solving process data can inform instruction. Australasian Journal of Educational Technology, 26.(5.), 585-606.

\section{Dancs, Katinka: Grade 5 and grade 6 students' knowledge of national symbols - results of a computer-based assessment}

Developing students' national identity is a developmental goal in school curricula, however we have scarce information about students' national identity. Our study aimed to assess their test performance related to national symbols, knowledge associated with national identity. National symbols are parts of the national culture, they are persons, events, places and artworks appearing in historical narratives. We gathered national symbols form school curricula through several steps and used them to develop a test. Our results showed that the test proved reliable, students achieved $64.78 \%$ on average. Older students performed better, no gender differences were found. Pupils' strength of national identity was also assessed. Grade 6 students showed had weaker identification, no gender differences were found. The connection between test performance and the strength of identification was also investigated. There is significant connection between the variables, but the correlation coefficients are low. Test performance is related to students' satisfaction with their school performance indicating that the test assessed knowledge appearing in the curricula. We used computer-based assessment and gathered data about pupils' test behaviour. No connection was found between test performance and time on test, however time is significantly correlated with the general liking of school. This outcome confirms that time is rather influenced by attitudes then students' knowledge. Our study is the first step to investigate the role of school in the process of national identity development.

Key words: elementary school, knowledge assessment, citizenship competence, national identity, computer-based assessment 